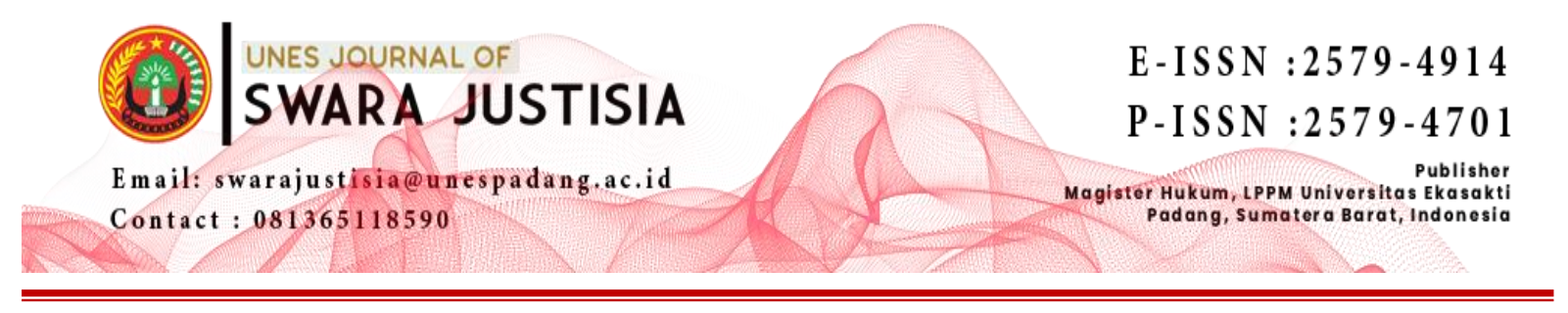

\title{
PENEGAKAN HUKUM TERHADAP TINDAK PIDANA HAK ATAS MEREK PELUMAS KENDARAAN BERMOTOR OLEH PENYIDIK DIREKTORAT RESERSE KRIMINAL KHUSUS POLDA SUMATERA BARAT (Analisis Laporan Polisi Nomor: LP/B/133/III/2018/SPKT.SBR)
}

\author{
${ }^{1}$ Yudha Legowo, ${ }^{2}$ Fahmiron, ${ }^{3}$ Iyah Faniyah, \\ ${ }^{1}$ Program Magister Ilmu Hukum, Universitas Ekasakti, Padang, Indonesia \\ Email: rizkyfebryand@ gmail.com \\ ${ }^{2}$ Program Magister Ilmu Hukum, Universitas Ekasakti, Padang, Indonesia \\ Email: fahmiron@gmail.com \\ ${ }^{3}$ Program Magister Ilmu Hukum, Universitas Ekasakti, Padang, Indonesia \\ Email: iyahfaniyah01@gmail.com
}

\begin{abstract}
ABSTRAK
Merek memiliki daya jual tinggi bagi pelaku usaha sehingga mendatangkan keuntungan. Terhadap penggunaan merek tanpa hak telah diancam pidana sebagaimana diatur dalam Pasal 100 Undang-Undang Nomor 20 Tahun 2016 tentang Merek dan Indikasi Geografis. Tindak pidana dibidang Merek terjadi di Kota Padang Pariaman dan ditangani oleh Ditreskrimsus Polda Sumbar, sebagaimana dalam Laporan Polisi Nomor: LP/B/133/III/2018/SPKT.SBR. Disamping melanggar hak kekayaan intelektual, tindakan tersebut juga berakibat pada konsumen sebagai pengguna dari suatu produk. Maka diperlukan penegakan hukum terhadap bentuk tindak pidana dibidang merek, guna wujud penegakan dan perlindungan hukum bagi masyarakat. Berdasarkan pembahasan dan analisis dapat disimpulkan sebagai berikut: Pertama, Penegakan hukum terhadap tindak pidana hak atas merek pelumas kendaraan bermotor oleh Penyidik Direktorat Reserse Kriminal Khusus Polda Sumatera Barat pada Laporan Polisi Nomor: LP/B/133/III/2018/SPKT.SBR diawali adanya laporan dari kuasa hukum PT. Federal Karyatama, kemudian dilakukan penyelidikan, penyidikan, hingga perkara tersebut dinyatakan lengkap (P-21) oleh Jaksa Penuntut Umum dan berdasarkan Putusan Nomor:226/ Pid.Sus/2018/PN.Pmn terhadap Masri Pgl Mas divonis bersalah dengan dijatuhi hukuman pidana penjara selama 8 bulan dengan masa percobaan selama 1 tahun. Kedua, Kendala yang dihadapi Penyidik yaitu pertama kendala faktor hukum dimana tindak pidana hak atas merek bersifat delik aduan, sehingga kepolisian hanya dapat bertindak setelah adanya laporan dari pemegang hak atas merek yang dirugikan. Kedua kendala faktor penegak hukum yaitu masih terbatasnya pelaksanaan pendidikan kejuruan bagi personil Subdit I Indagsi Direktorat Reserse Kriminal Khusus Polda Sumatera Barat sehingga berpengaruh pada keoptimalan dalam pelaksanaan tugas penyidikan tindak pidana hak atas merek. Ketiga faktor masyarakat yaitu kurangnya partisipasi masyarakat dalam memberikan informasi terkait adanya dugaan tindak pidana hak atas merek.
\end{abstract}

Kata Kunci: Tindak Pidana, Merek, Motor 


\section{PENDAHULUAN}

Pengaruh globalisasi di segala bidang kehidupan masyarakat, baik di bidang sosial, ekonomi, maupun budaya semakin mendorong laju perkembangan perekonomian masyarakat. Di samping itu, dengan semakin meningkatnya perkembangan teknologi informasi dan sarana transportasi, telah menjadikan kegiatan di sektor perdagangan baik barang maupun jasa mengalami perkembangan yang sangat pesat. Kecenderungan akan meningkatnya arus perdagangan barang dan jasa tersebut akan terus berlangsung secara terus menerus sejalan dengan pertumbuhan ekonomi nasional yang semakin meningkat. ${ }^{1}$

Kondisi yang demikian pada satu pihak mempunyai manfaat bagi konsumen karena kebutuhan konsumen akan barang dan jasa yang diinginkan dapat terpenuhi serta semakin terbuka lebar kebebasan untuk memilih aneka jenis dan kualitas sesuai dengan keingingan dan kemampuan konsumen. Namun disisi lain dalam fenomena tersebut dapat mengakibatkan antar pelaku usaha terjadi persaingan dalam mengadakan usahanya. ${ }^{2}$

Para pelaku usaha dalam menjalankan usahanya memberikan ciri atas barang dari hasil produksi yaitu penggunaan merek dalam produknya. Keberadaan merek menjadi sangat penting untuk menunjukkan reputasi dari produk barang dan jasa. Dengan demikian, pembaharuan perlindungan merek terkait dengan hukum yang senantiasa mampu memenuhi perkembangan yang ada. ${ }^{3}$

Merek sebagai salah satu karya intelektual manusia yang erat hubungannya dengan kegiatan ekonomi dan perdagangan dimana merek memegang peranan yang sangat penting didalam kegiatan pelaku usaha barang dan jasa. Sebagaimana diatur didalam Pasal 1 UndangUndang Nomor 20 Tahun 2016 tentang Merek Dan Indikasi Geografis, menyebutkan bahwa:

Merek adalah tanda yang dapat ditampilkan secara grafis berupa gambar, logo, nama, kata, huruf, angka, susunan warna, dalam bentuk 2 (dua) dimensi dan/atau 3 (tiga) dimensi, suara, hologram, atau kombinasi dari 2 (dua) atau lebih unsur tersebut untuk membedakan barang dan/atau jasa yang diproduksi oleh orang atau badan hukum dalam kegiatan perdagangan barang dan/atau jasa.

Merek merupakan jati diri dari sebuah produk, dimana pembeli akan lebih gampang untuk menentukan pilihan berdasarkan merek yang diinginkan. Merek ini bisa membuat suatu barang memiliki pasar sendiri dengan kebesaran nama yang telah diciptakan. ${ }^{3}$

Konsumen membutuhkan waktu lebih lama untuk mengevaluasi suatu produk, namun akan segera menentukan pilihan pada saat telah melihat merek yang mereka kenal yang pada akhirnya akan meningkatkan keuntungan bagi perusahaan atau pelaku usaha. ${ }^{4}$

Merek adalah elemen kunci dalam hubungan pelaku usaha dengan konsumen, serta mendukungnya dengan marketing mix (strategi produk, harga, distribusi, promosi) dan strategi selling. Pada umumnya merek terbaik akan memberikan jaminan suatu kualitas. Didalam merek mempunyai dua unsur, yaitu brand name yang terdiri dari huruf-huruf atau kata-kata yang dapat terbaca, serta brand mark yang berbentuk simbol, desain, atau warna tertentu yang spesifik. Kedua unsur dari kedua merek tersebut selain berguna untuk Geografis.

1 Penjelasan Umum Atas Undang-Undang Nomor 20 Tahun 2016 tentang Merek dan Indikasi

${ }^{2}$ Rachmadi Usman, Hukum Hak dan Kekayaan Intelektual, Perlindungan dan Dimensi Hukumnya di Indonesia. PT. Alumni, Bandung, 2003, hlm. 329.

${ }^{3}$ Munir Fuadi, Pengantar Hukum Bisnis, PT. Citra Aditya Bakti, Bandung, 2012, hlm. 203.

${ }^{4}$ http://e-journal.uajy.ac.id/1202/2/1KOM03409.pdf, diakses pada 17 Desember 2020, Pkl.02.00 Wib. 
membedakan suatu produk dari produk pesaingnya juga berguna untuk mempermudah konsumen mengenali dan mengidentifikasi barang atau jasa yang hendak dibeli. ${ }^{5}$

Mengingat pentingnya keberadaan merek didalam sebuah usaha, maka telah dilindungi oleh Pasal 100 Undang-Undang Nomor 20 Tahun 2016 tentang Merek Dan Indikasi Geografis, menyebutkan bahwa:

Setiap Orang yang dengan tanpa hak menggunakan Merek yang sama pada keseluruhannya dengan Merek terdaftar milik pihak lain untuk barang dan/atau jasa sejenis yang diproduksi dan/atau diperdagangkan, dipidana dengan pidana penjara paling lama 5 (lima) tahun dan/atau pidana denda paling banyak Rp 2.000.000.000,00 (dua miliar rupiah).

Bentuk perlindungan terhadap merek juga diatur didalam Undang-Undang Nomor 31 Tahun 2000 tentang Desain Industri, yang mana berkaitan adanya desain didalam sebuah merek yang digunakan didalam suatu barang. Dimana karya seseorang guna mendukung persaingan usaha yang sehat, berkeadilan, pelindungan konsumen serta pelindungan usaha mikro, kecil, dan menengah dan industri dalam negeri.

Didalam sebuah merek terdapat desain yang mana patut dilindungi sebab pemegang hak desain industri memiliki hak eksklusif untuk melaksanakan hak desain industri yang dimilikinya dan untuk melarang orang lain yang tanpa persetujuannya membuat, memakai, menjual, mengimpor, mengekspor, dan mengedarkan barang yang diberi hak desain industri dari pemegang hak tersebut. Sebagaimana disebut didalam Pasal 1 Undang-Undang Nomor 31 Tahun 2000 tentang Desain Industri, menyebutkan bahwa:

Desain Industri adalah suatu kreasi tentang bentuk, konfigurasi, atau komposisi garis atau warna, atau garis dan warna, atau gabungan daripadanya yang berbentuk tiga dimensi atau dua dimensi yang memberikan kesan estetis dan dapat diwujudkan dalam pola tiga dimensi atau dua dimensi serta dapat dipakai untuk menghasilkan suatu produk, barang, komoditas industri, atau kerajinan tangan.

Selanjutnya dalam Pasal 9 Ayat (1) Undang-Undang Nomor 31 Tahun 2000 tentang Desain Industri, menyebutkan bahwa:

Pemegang Hak desain industri memiliki hak ekslusif untuk melaksanakan Hak Desain Industri yang dimilikinya dan melarang orang lain yang tanpa persetujuannya membuat, memakai, menjual, mengimpor, mengekspor, dan/atau mengedarkan barang yang diberi Hak desain industri.

Di dalam sebuah desain industri terdapat lisensi atau izin yang diberikan oleh pemegang hak desain industri kepada pihak lain melalui suatu perjanjian berdasarkan pada pemberian hak untuk menikmati manfaat ekonomi dari suatu desain industri yang diberi perlindungan dalam jangka waktu tertentu dan syarat tertentu. Maka dapat dikatakan bahwa apabila suatu merek sudah dimiliki oleh seseorang maka orang lain tidak boleh membuat produk yang sama ataupun yang menyerupai berupa gambar, logo sehingga tidak ada hak kekayaan intelektual orang yang terlanggar. ${ }^{6}$

\footnotetext{
${ }^{5}$ Rachmadi Usman, Op Cit, hlm. 317

${ }^{6}$ Abdulkadir Muhammad, Kajian Hukum Hak Kekayaan Intelektual, Citra Aditya Bakti, Bandung, 2015, hlm. 9.
} 
Pelanggaran terhadap hak merek merupakan perbuatan hukum yang memiliki sanksi pidana. Kebutuhan akan perlindungan hukum di bidang merek semakin meningkat. ${ }^{7}$ Sebagaimana disebutkan dalam Pasal 54 Ayat (1) Undang-Undang Nomor 31 Tahun 2000 tentang Desain Industri, menyebutkan bahwa:

Barang siapa dengan sengaja dan tanpa hak melakukan perbuatan sebagaimana dimaksud dalam Pasal 9 dipidana dengan pidana penjara paling lama 4 (empat) tahun dan/atau denda paling banyak Rp300.000.000,00 (tiga ratus juta rupiah)

Adanya ancaman pidana tersebut disebabkan banyaknya pelaku usaha yang melakukan peniruan terhadap merek-merek. Terlebih pula ketika dunia perdagangan semakin maju serta alat transportasi yang semakin baik juga dengan diberlakukannya promosi, maka wilayah pemasaran barangpun menjadi lebih luas. Keadaan seperti ini menambah pentingnya merek yaitu untuk membedakan asal-usul barang dan kualitasnya juga menghindari peniruan.

Berdasarkan penelusuran penulis terhadap tindak pidana pemalsuan merek yang terjadi di wilayah Sumatera Barat, tidak begitu banyak terungkap seperti halnya kasus-kasus pemalsuan merek minuman beralkohol dan pena my gel yang ditangani oleh Direktorat Reserse Kriminal Khusus Polda Sumatera Barat dalam hal ini Subdit I yang menangani tindak pidana dibidang Industri, Perdagangan dan Asuransi (Indagsi).

Kendati demikian terhadap tindak pidana dibidang hak atas Merek yang terkait dengan penggunaan hak desain industri yang dilakukan tanpa izin dari si pemilik hak eksklusif untuk membuat, memakai, menjual, mengimpor, mengekspor dan atau mengedarkan barang yang diberi Hak Desain Industri, merupakan delik aduan sehingga diperlukan adanya laporan dari pihak yang secara langsung mempunyai hak atas merek ataupun pemilik hak desain Industi.

Terungkap adanya pemalsuan merek terjadi di wilayah hukum Polda Sumatera Barat, tepatnya di daerah Simpang Lintas Lubuk Alung Korong Pasa Kandang Kenagarian Bala Hilia Kecamatan Lubuk Alung Padang Pariaman.8 Berdasarkan laporan polisi nomor LP/B/133/III/2018/SPKT.SBR yang dibuat oleh kuasa hukum pihak PT. Federal Karyatama selaku pemegang Federal Oil Ultratec dan Federal Oil Federal Matic, merupakan pelumas atau oli sepeda motor. Sebagaimana berdasarkan sertifikat merek nomor: IDM000279300, tanggal 12 November 2010 berlaku selama 10 tahun, terhitung sejak tanggal penerimaan yang diterbitkan oleh Kementerian Hukum dan Hak Azasi Manusia Republik Indonesia Dirjen HKI u.b. Direktur Merek, dengan merek Federal Ultratec tercatat atas nama pemilik PT. Federal Karyatama dan permintaan perpanjangan Pendaftaran Merek Federal Oil Ultratec Nomor Agenda: R002010006713.

Adapun bentuk perbuatan dalam laporan polisi tersebut adalah adanya seseorang yang memperdagangkan atau mengedarkan barang berupa pelumas atau oli sepeda motor isi 0,8 Liter dengan merek Federal Oil Ultratec dan Federal Oil Federal yang mana diduga palsu. Maka atas laporan tersebut diproses oleh penyidik Direktorat Reserse Kriminal Khusus Polda Sumatera Barat, guna dilakukan penegakan hukum atas perbuatan tersebut. Dari hasil uji laboratorium terhadap sample pelumas atau oli sepeda motor isi 0,8 Liter merek Federal

\footnotetext{
${ }^{7}$ Sophar Maru Hutagalung, Hak Cipta Kedudukan \& Peranannya dalam Pembangunan, Sinar Grafika, Jakarta, 2012, hlm. 126

${ }^{8}$ https://www. kompas.com, Polda Sumbar Sita Ribuan Oli Palsu, Pemilik Toko Jadi Tersangka diakses pada 6 Februari 2021, Pkl. 04.00 Wib
} 
Oil Ultratec dan Federal Oil Federal Matic yang didapatkan dari Toko Aneka Sepeda milik tersangka, yang tidak memenuhi standar atau bukan merupakan produk yang di produksi dari PT. Federal Karyatama, namun menyerupai produk pelumas produksi PT. Federal Karyatama.

Dimana disebutkan bahwa terdapat ciri-ciri khusus yang membedakan antara produk PT. Federal Karyatama dengan produk yang dijual oleh tersangka terdapat perbedaan sebagai berikut:

1. Profil ulir dan snap botol pada oli Ultratec yang dibeli dari Aneka sepeda jauh melebihi melebihi garis putih sedangkan Standar dari PT. Federal Karyatama hanya sedikit melebihi garis putih;

2. Pada Profil kulit jeruk yang dibeli dari Aneka sepeda tidak tegas, bentuknya tidak teratur sedangkan Standar dari PT. Federal Karyatama bentunya tegas, teratur dan jelas;

3. Pada label yang dibeli dari Toko Aneka Sepeda jika diberi sinar ultra violet akan terdapat tulisan Federal Oil namun bentuk tulisannya tidak tegas dan tidak sesuai standar sedangkan Standar dari PT. Federal Karyatama jika diberi sinar ultra violet akan terdapat tulisan Federal Oil yang jelas dan tegas;

4. Pada bagian bawah botol yang dibeli dari Toko Aneka Sepeda terdapat kode-kode namun tulisannya tidak jelas dan tegas tidak sesuai dengan Standar PT. Federal Karyatama yang bentuknya jelas dan tegas.

Akibat perbuatan tersangka yaitu memperdagangkan pelumas kendaraan bermotor merek Ultratec dan Federal Oil Federal yang bukan merupakan hasil produksi dari PT. Federal Karyatama, maka akan mengurangi volume penjualan Pelumas atau Oli sepeda motor isi 0,8 Liter merek Federal Oil Ultratec dan Federal Oil Federal yang merupakan hasil produksi dari PT. Federal Karyatama sehingga menimbulkan kerugian dari segi pendapatan hasil penjualan PT. Federal Karyatama.

\section{PEMBAHASAN}

\section{A. Penegakan Hukum Terhadap Tindak Pidana Hak Atas Merek Pelumas Kendaraan Bermotor Oleh Penyidik Direktorat Reserse Kriminal Khusus Polda Sumatera Barat Pada Laporan Polisi Nomor: LP/B/133/III/2018/SPKT.SBR}

Penegakan hukum merupakan usaha untuk mewujudkan ide-ide dan konsepkonsep hukum yang diharapkan rakyat menjadi kenyataan. Proses penegakan hukum pidana merupakan suatu rangkaian proses hukum yang dimulai dari tahap penyelidikan, penyidikan, penuntutan dan pengadilan. Penegakan hukum dilaksanakan oleh penegak hukum melalui sistem peradilan pidana. ${ }^{9}$ Kepolisian sebagai salah satu penegak hukum merupakan lembaga sub sistem dalam sistem peradilan pidana yang mempunyai kedudukan pertama dan utama. Kedudukan yang demikian oleh Harkristuti Harkrisnowo dikatakan sebagai the gate keeper of the criminal justice system. Tugas polisi dalam rangkaian sistem peradilan pidana adalah melakukan penyidikan yang berujung pada dihasilkannya Berita Acara Pemeriksaan (BAP). ${ }^{10}$

${ }^{9}$ Dellyana Shanti, Konsep Penegakan Hukum, Loc.Cit, hlm. 37.

${ }^{10}$ Harkristuti Harkrisnowo, Rekonstruksi Konsep Pemidanaan: Suatu Gugatan Terhadap Proses Legislasi dan Pemidanaan di Indonesia, Orasi pada Upacara Pengukuhan Guru Besar Tetap dalam Ilmu Hukum di FH UI Depok, 8 Maret 2003, hlm. 2. 
Berdasarkan hasil penelitan pada perkara tindak pidana hak atas merek pelumas kendaraan bermotor sebagaimana dalam Laporan Polisi Nomor: LP/133/III/2018/SPKT.SBR yang ditangani Subdit I Indagsi (Industri, Perdagangan dan Asuransi) Direktorat Reserse Kriminal Khusus (Ditreskrimsus) Kepolisian Daerah Sumatera Barat. Menurut AKBP Yunizar Yudhistira, penegakkan hukum dalam perkara ini hanya dapat dilakukan setelah adanya pengaduan dari pihak yang dirugikan atau yang telah menjadi korban, karena dalam tindak pidana hak atas merek ini merupakan tindak pidana dengan delik aduan dan yang berwenang dalam penanganan perkara ini yakni Subdit I Indagsi Ditreskrimsus Polda Sumatera Barat, karena perkara ini merupakan tindak pidana khusus yang diatur dalam Undang-undang Nomor 31 Tahun 2000 tentang Desain Industri Jo Undang-undang Nomor 20 Tahun 2016 tentang Merek dan Indikasi Geografis Jo Undang-undang Nomor 8 Tahun 1999 tentang Perlindungan Konsumen.

Sebagaimana yang diketahui pada bab sebelumnya, dimana perakara ini bermula dari adanya laporan dari pelapor atas nama Mohamad Rofiaddin (saksi pelapor) berdasarkan Surat Kuasa No.FK/04-010/0005/EXT/011/2/2018 tanggal 12 Februari 2018 dari Ari Sutanto selaku Direktur PT. Federal Karyatama untuk membuat laporan atau pengaduan di Polda Sumatera Barat yang diterima oleh Bripka Dalsal Candra, sebagai Penyidik Pembantu dan dibawah perintah AKBP Yunizar Yudhistira, selaku Kasubdit Indagsi Ditreskrimsus Polda Sumatera Barat atas dugaan telah terjadinya tindak pidana hak atas merek yang diduga dilakukan oleh pemilik dari bengkel/toko Aneka Sepeda yang beralamat di Lubuk Alung, Kabupaten Padang Pariaman Sumatera Barat yang kemudian dituangkan dalam Laporan Polisi Nomor: LP/B/133/III/2018/SPKT tertanggal 21 Maret 2018.

Berdasarkan laporan tersebut, kemudian Penyidik Ditreskrimsus Polda Sumatera Barat melaksanakan penegakan hukum dengan rangkaian kegiatan penyidikan yang didahului dengan penyelidikan dengan mengunjungi tempat kejadian perkara guna menemukan dan mengumpulkan bukti permulaan yang cukup dengan Surat Perintah Penggeledahan Nomor: Sp.Dah/03/III/2018/ Ditreskrimsus tanggal 21 Maret 2018, telah dilakukan penggeledahan terhadap Toko Aneka Sepeda. Dimana dari hasil penggeledahan tersebut, Penyidik telah melakukan upaya hukum penyitaan terhadap barang bukti yang berhubungan dengan perkara berdasarkan Surat Perintah Penyitaan Nomor: Sp.Sita/03/III/ 2018/Ditreskrimsus tanggal 21 Maret 2018, telah dilakukan penyitaan terhadap barang bukti sebagaimana yang telah disebutkan dalam bab sebelumnya. Dalam hal ini terhadap tersangka Penyidik tidak melakukan upaya penangkapan dan penahanan.

Berdasarkan penyitaan barang bukti dari hasil penyelidikan tersebut kemudian Penyidik Ditreskrimsus Polda Sumatera Barat menerbitkan Surat Perintah Penyidikan Nomor: Sp.Sidik/19/III/2018/Ditreskrimsus pada tanggal 21 Maret 2018 yang kemudian diterbitkannya Surat Pemberitahuan Dimulainya Penyidikan Nomor: SPDP/09/III/2018/Ditreskrimsus tanggal 26 Maret 2018 ke Kejaksaan Negeri Padang Pariaman. Adapun dalam melaksanakan penyidikan, penyidik telah melakukan pemanggilan serta mengadakan pemeriksaan terhadap saksi-saksi sebagai berikut:

1. Terhadap Saksi Mohamad Rofiaddin, SH tidak dilakukan pemanggilan dan tidak diterbitkan surat panggilan, karena saksi pada saat membuat laporan dan pengaduan 
setelah selesai pemeriksaan produk oli sepeda motor pada toko aneka sepeda langsung dilakukan pemeriksaan sebagai saksi dengan berita acara pemeriksaan tanggal 21 Maret 2018.

2. Terhadap Saksi Rossy Melinda Gultom tidak dilakukan pemanggilan dan tidak diterbitkan surat panggilan, karena saksi pada saat membuat laporan dan pengaduan setelah selesai pemeriksaan produk oli sepeda motor pada toko aneka sepeda langsung dilakukan pemeriksaan sebagai saksi dengan berita acara pemeriksaan tanggal 21 Maret 2018 serta pemeriksaan lanjutan dengan berita acara pemeriksaan tanggal 3 April 2018.

3. Terhadap Saksi Muhammad Hadi Ardinsyah, Nst Pgl Hadi tidak dilakukan pemanggilan dan tidak diterbitkan surat panggilan dan telah dilakukan pemeriksaan dengan Berita Acara Pemeriksaan tanggal 21 Maret 2018.

4. Berdasarkan Surat Panggilan Nomor: S.Pgl/32/III/2018/Ditreskrimsus, tanggal 26 Maret 2018 telah dipanggil Saksi Andre Pgl Andre, telah dilakukan pemeriksaan dengan Berita Acara Pemeriksaan tanggal 26 Maret 2018.

5. Berdasarkan Surat Panggilan Nomor: S.Pgl/33/III/2018/Ditreskrimsus, tanggal 26 Maret 2018 telah dipanggil Saksi Asep Logiman Saputra Pgl Asep, telah dilakukan pemeriksaan dengan Berita Acara Pemeriksaan tanggal 26 Maret 2018;

6. Berdasarkan Surat Panggilan Nomor: S.Pgl/34/III/2018/Ditreskrimsus, tanggal 26 Maret 2018 telah dipanggil Saksi Muhamad Nasir Pgl Nasir, telah dilakukan pemeriksaan dengan Berita Acara Pemeriksaan tanggal 26 Maret 2018.

7. Berdasarkan Surat Panggilan Nomor: S.Pgl/35/III/2018/Ditreskrimsus, tanggal 26 Maret 2018 telah dipanggil Saksi Zulfahmi, telah dilakukan pemeriksaan dengan Berita Acara Pemeriksaan tanggal 26 Maret 2018.

8. Terhadap Saksi Guslim Pgl Agus tidak dilakukan pemanggilan dan tidak diterbitkan surat panggilan dan telah dilakukan pemeriksaan dengan Berita Acara Pemeriksaan tanggal 22 Maret 2018.

9. Terhadap Saksi Bunga Siciana Pgl Bunga tidak dilakukan pemanggilan dan tidak diterbitkan surat panggilan dan telah dilakukan pemeriksaan dengan Berita Acara Pemeriksaan tanggal 26 Maret 2018.

Dalam perkara ini, Penyidik juga melakukan pemanggilan terhadap ahli untuk memberikan keterangan terkait dengan perkara tindak pidana hak atas merek pelumas kendaraan bermotor, adapun ahli yang diperiksa sebagai berikut:

1. Ahmad Rifadi, S.H., M.Si Pgl Adi Kepala Seksi Pelayanan Hukum dan Litigasi Direktorat Hak Cipta dan Desain Industri, Direktorat Jenderal Kekayaan Intelektual Kementrian Hukum dan Hak Asasi Manusia Republik Indonesia dengan surat penunjukan No. 22/04/Yankum/2018 tanggal 02 April 2018.

2. Nova Susanti, S.H Kepala Seksi Pertimbangan Hukum dan Litigasi Subdit Pelayanan Hukum dan Fasilitasi Komisi Banding Direktorat Merek dan Indikasi Geografis Ditjen Kekayaan Intelektual Kementerian Hukum dan Hak Asasi Manusia Republik Indonesia dengan surat penujukan No. HKI.4.HI.06.06.06-156/2018 tanggal 5 April 2018.

3. M. Syahrial, MM Kepala Bidang Perlindungan Konsumen dan Tertib Niaga Dinas Perindustrian Perdagangan Provinsi Sumatera Barat dengan surat penunjukan No. SPT/Perindag/V/2018, tanggal 11 Mei 2018.

Berdasarkan dari keterangan Saksi, Ahli, Surat, Petunjuk dan keterangan Tersangka serta dikaitkan dengan barang bukti maka benar diduga telah terjadi tindak pidana dengan sengaja memperdagangkan barang berupa pelumas atau oli sepeda motor 
yang tanpa hak menggunakan Merek dan Desain Industri pelumas merek Federal Oil Ultratec dan Federal Oil Federal Matic yang terdaftar atas nama PT. Federal Karyatama, yang ditemukan pada hari Rabu tanggal 21 Maret 2018 sekira pukul 16.00 wib di Toko Aneka Sepeda yang berada di Simpang Lintas Lubuk Alung Korong Pasa Kandang Kenagarian Bala Hilia Kecamatan Lubuk Alung Padang Pariaman milik tersangka Masri, umur 59 tahun, Suku minang (Panyalai), Agama Islam, Pekerjaan Dagang, alamat di Simpang Lintas Lubuk Alung Korong Pasa Kandang Kenagarian Bala Hilia Kecamatan Lubuk Alung Padang Pariaman.

Sehingga terhadap tersangka, disangkakan telah melanggar Pasal 100 dan atau Pasal 102 Undang-undang Nomor 20 Tahun 2016 tentang Merek dan atau Pasal 54 Ayat (1) Undang-undang Nomor 31 Tahun 2000 tentang Desain Industri dan atau Pasal 62 Ayat (1) Juncto Pasal 8 Ayat (1) huruf (a) Undang-undang Nomor 8 Tahun 1999 tentang perlindungan Konsumen. Bunyi dan unsur-unsur pasal tersebut sebagai berikut:

Pasal 100 Undang-undang Nomor 20 Tahun 2016 tentang Merek dan Indikasi Geografis:

Ayat (1) Setiap Orang yang dengan tanpa hak menggunakan Merek yang sama pada keseluruhannya dengan Merek terdaftar milik pihak lain untuk barang dan/atau jasa sejenis yang diproduksi dan/atau diperdagangkan, dipidana dengan pidana penjara paling lama 5 (lima) tahun dan/atau pidana denda paling banyak Rp 2.000.000.000,00 (dua miliar rupiah).

Ayat (2) Setiap Orang yang dengan tanpa hak menggunakan Merek yang mempunyai persamaan pada pokoknya dengan Merek terdaftar milik pihak lain untuk barang dan/atau jasa sejenis yang diproduksi dan/atau diperdagangkan, dipidana dengan pidana penjara paling lama 4 (empat) tahun dan/atau denda paling banyak Rp2.000.000.000,00 (dua miliar rupiah).

Adapun unsur-unsur yang terdapat dalam Pasal 100 Ayat (1) Undang-undang Nomor 20 Tahun 2016 tentang Merek dan Indikasi Geografis yang terpenuhi sebagai berikut:

\section{Setiap orang}

Bahwa yang dimaksud setiap orang adalah orang atau subjek hukum yang dalam hal ini adalah tersangka Masri Pgl Mas, tempat tanggal lahir Sikabu pada tanggal 1 Februari 1959, Suku Minang (Panyalai), Agama Islam, Pekerjaan Dagang (Pemilik Toko Aneka Sepeda), Jenis kelamin Laki-laki, Kewarganegaraan Indonesia, Pendidikan SD (Tidak tamat), Alamat Simpang Lintas Lubuk Alung Korong Pasa Kandang Nagari Bala Hilia Kecamatan Lubuk Alung Kabupaten Padang Pariaman, secara fisik maupun mental tidak ada halangan untuk mempertanggung jawabkan perbuatanya secara hukum.

Hal tersebut sesuai dengan dokumen perizinan Toko Aneka Sepeda yang beralamat di Simpang Lintas Lubuk Alung Korong Pasa Kandang Nagari Bala Hilia Kecamatan Lubuk Alung Kabupaten Padang Pariaman, yaitu Surat Izin Usaha Perdagagan (SIUP) Kecil Tanda Daftar Perusahaan Persekutuan Komanditer (CV) Nomor TDP 030434602787 Nama Prusahaan CV. Aneka Jaya tanggal 15 Juni 2012 atas nama penanggung jawab perusahaan Masri. 


\section{Tanpa hak menggunakan Merek yang sama pada keseluruhannya dengan Merek terdaftar milik pihak lain untuk barang dan/atau jasa sejenis yang diproduksi dan/atau diperdagangkan.}

Tersangka Masri Pgl Mas telah memperdagangkan Merek yang sama pada keseluruhannya dan atau mempunyai persamaan yang sama pada pokoknya dengan Merek terdaftar milik PT. Federal Karyatama untuk barang dan/atau jasa sejenis berupa oli merek Ultratec $20 \mathrm{~W}-50$ isi 0,8 liter dan Federal Matic 30 isi 0,8 liter yang ditemukan pada hari Rabu tanggal 21 Maret 2018 sekira pukul 16.00 wib di Toko Aneka Sepeda yang berada di Simpang Lintas Lubuk Alung Korong Pasa Kandang Kenagarian Bala Hilia Kecamatan Lubuk Alung Padang Pariaman di Toko Aneka Sepeda milik tersangka Masri Pgl Mas.

Pasal 102 Undang-undang Nomor 20 Tahun 2016 tentang Merek dan Indikasi Geografis:

Setiap Orang yang memperdagangkan barang dan/atau jasa dan/atau produk yang diketahui atau patut diduga mengetahui bahwa barang dan/atau jasa dan/atau produk tersebut merupakan hasil tindak pidana sebagaimana dimaksud dalam Pasal 100 dan Pasal 101 dipidana dengan pidana kurungan paling lama 1 (satu) tahun atau denda paling banyak Rp200.000.000,00 (dua ratus juta rupiah).

Adapun unsur-unsur yang terdapat dalam Pasal 102 Undang-undang Nomor 20 Tahun 2016 tentang Merek dan Indikasi Geografis yang terpenuhi sebagai berikut:

\section{a. Setiap orang}

Bahwa yang dimaksud setiap orang adalah orang atau subjek hukum yang dalam hal ini adalah tersangka Masri Pgl Mas, tempat tanggal lahir Sikabu pada tanggal 1 Februari 1959, Suku Minang (Panyalai), Agama Islam, Pekerjaan Dagang (Pemilik Toko Aneka Sepeda), Jenis kelamin Laki-laki, Kewarganegaraan Indonesia, Pendidikan SD (Tidak tamat), Alamat Simpang Lintas Lubuk Alung Korong Pasa Kandang Nagari Bala Hilia Kecamatan Lubuk Alung Kabupaten Padang Pariaman, secara fisik maupun mental tidak ada halangan untuk mempertanggungjawabkan perbuatanya secara hukum.

b. Memperdagangkan barang dan/atau jasa dan/atau produk yang diketahui atau patut diduga mengetahui bahwa barang dan/atau jasa dan/atau produk tersebut merupakan hasil tindak pidana sebagaimana dimaksud dalam Pasal 100 dan Pasal 101.

Dalam hal ini tersangka Masri Pgl Mas telah memperdagangkan barang berupa pelumas merek Federal Ultratec 20W-50 isi 0,8 liter dan Federal Matic 30 isi 0,8 Liter dengan harga dibawah Standar harga oli merek tersebut dan tersangka Masri telah mengetahui bahwa oli tersebut bukan merupakan asli dan tersangka Masri Pgl Masri mendapatkan atau membeli oli untuk diperdagangkan tersebut tidak dari Distributor resmi Oli merek Federal.

Bahwa berdasarkan keterangan Saksi Asep Logiman, saksi mengetahui bahwa oli merek Federal Utratec dan oli merek Federal Matic yang diperdagangkan pada Toko Aneka Sepeda tersebut didapatkan atau dibeli bukan dari Distributor resmi Oli Federal Utratec 20W-50 isi 0,8 liter dan Federal Matic 30 isi 0,8 Liter, dan saksi 
Asep Logiman mengetahui jika oli tersebut dijual dibawah harga standar oli merek Federal Ultratec 20W-50 isi 0,8 liter dan Federal Matic 30 isi 0,8 Liter.

Pasal 54 Ayat (1) Undang-undang Nomor 31 Tahun 2000 tentang Desain Industri:

Barangsiapa dengan sengaja dan tanpa hak melakukan perbuatan sebagaimana dimaksud dalam Pasal 9 dipidana dengan pidana penjara paling lama 4 (empat) tahun dan/atau denda paling banyak Rp. 300.000.000,00 (tiga ratus juta rupiah).

Adapun unsur-unsur yang terdapat dalam Pasal 54 Ayat (1) Undang-undang Nomor 31 Tahun 2000 tentang Desain Industrri yang terpenuhi sebagai berikut:

\section{a. Barang siapa}

Yaitu orang atau subjek hukum dalam hal ini adalah tersangka Masri Pgl Mas, tempat tanggal lahir Sikabu pada tanggal 1 Februari 1959, Suku Minang (Panyalai), Agama Islam, Pekerjaan Dagang (Pemilik Toko Aneka Sepeda), Jenis kelamin Laki-laki, Kewarganegaraan Indonesia, Pendidikan SD (Tidak tamat), Alamat Simpang Lintas Lubuk Alung Korong Pasa Kandang Nagari Bala Hilia Kecamatan Lubuk Alung Kabupaten Padang Pariaman, secara fisik maupun mental tidak ada halangan untuk mempertanggung jawabkan perbuatanya secara hukum.

\section{b. Dengan sengaja}

Dalam hal ini tersangka Masri Pgl Mas telah dengan sengaja memperdagangkan oli merek Federal Ultratec dan oli merek Federal Matic yang bukan hasil Produksi PT.Federal Karyatama selaku pemegang merek.

\section{c. Tanpa hak melakukan perbuatan sebagaimana dimaksud dalam Pasal 9} Undang-undang Nomor 31 Tahun 2000 tentang Desain Industri:

Dalam hal ini tersangka Masri telah memperdagngkan oli merek Federal Ultratec dan Oli merek Federal Matic yang bukan merupakan hasil produksi pemegang merek dan tidak mendapatkan izin dan atau persetujuan dari pemegang merek yaitu PT. Federal Karyatama.

Pasal 62 Ayat (1) Juncto Pasal 8 Ayat (1) huruf a Undang-undang Nomor 8 Tahun 1999 tentang Perlindungan Konsumen:

Pelaku usaha yang melanggar ketentuan sebagaimana dimaksud dalam Pasal 8, Pasal 9, Pasal 10, Pasal 13 Ayat (2), Pasal 15, Pasal 17 Ayat (1) huruf a, huruf b, huruf, c, huruf e, Ayat (2) dan Pasal 18 dipidana dengan pidana penjara paling lama 5 (lima) tahun atau pidana denda paling banyak Rp.2.000.000.000,- (dua milyar rupiah).

Pasal 8 Ayat (1) Huruf a

Pelaku usaha dilarang memproduksi dan/atau memperdagang-kan barang dan/atau jasa yang tidak memenuhi atau tidak sesuai dengan Standar yang dipersyaratkan dan ketentuan peraturan perundang undangan.

Adapun unsur-unsur yang terdapat dalam Pasal 62 Ayat (1) Juncto Pasal 8 Ayat (1) huruf a dan e yang terpenuhi sebagai berikut:

\section{a. Pelaku usaha}

Bahwa yang dimaksud pelaku usaha adalah setiap orang perseorangan warga negara Indonesia yang melakukan usaha di bidang perdagangan adalah orang 
atau subjek hukum yang dalam hal ini adalah tersangka Masri Pgl Mas, tempat tanggal lahir Sikabu pada tanggal 1 Februari 1959, Suku Minang (Panyalai), Agama Islam, Pekerjaan Dagang (Pemilik Toko Aneka Sepeda), Jenis kelamin Laki-laki, Kewarganegaraan Indonesia, Pendidikan SD (Tidak tamat), Alamat Simpang Lintas Lubuk Alung Korong Pasa Kandang Nagari Bala Hilia Kecamatan Lubuk Alung Kabupaten Padang Pariaman, secara fisik maupun mental tidak ada halangan untuk mempertanggung jawabkan perbuatanya secara hukum.

b. Memperdagangkan barang

Tersangka Masri Pgl Mas adalah pemilik Toko Aneka Sepeda yang beralamat di Simpang Lintas Lubuk Alung Korong Pasa Kandang Nagari Bala Hilia Kecamatan Lubuk Alung Kabupaten Padang Pariaman, bergerak dibidang usaha perdagangan atau memperjual belikan barang berupa onderdil atau sperpart sepeda motor dan juga berbagai macam jenis atau merek oli sepeda motor diantaranya oli merek Ultratec $20 \mathrm{~W}-50$ isi 0,8 liter dan Federal Matic 30 isi 0,8 liter.

c. Tidak memenuhi atau tidak sesuai dengan Standar yang dipersyaratkan dan ketentuan peraturan perundang undangan

Barang berupa oli merek Ultratec 20 W-50 isi 0,8 liter dan Federal Matic 30 isi 0,8 liter yang diperdagangkan atau yang diperjualbelikan oleh tersangka Masri Pgl Masri tidak memenuhi Standar yang dipersyaratkan sebagaimana hasil pengujian terhadap sampel barang bukti dari Pusat Penelitian dan Pengembangan Teknologi Minyak dan Gas Bumi (LEMIGAS).

Menurut Bripka Dalsal Candra, setelah proses penyidikan terhadap perkara tindak pidana hak atas merek pelumas kendaraan bermotor sebagaimana dalam Laporan Polisi Nomor: LP/B/133/III/ 2018/SPKT.SBR tanggal 21 Maret 2018 atas nama terlapor Masri Pgl Mas (Pemilik Toko Aneka Sepeda) yang beralamat di Simpang Lintas Lubuk Alung Korong Pasa Kandang Nagari Bala Hilia Kecamatan Lubuk Alung Kabupaten Padang Pariaman, telah selesai dan dinyatakan lengkap oleh Jaksa Penuntut Umum Kejaksaan Negeri Padang Pariaman, dan terhadap tersangka disangkakan melanggar Pasal 100 dan atau Pasal 102 Undang-undang Nomor 20 Tahun 2016 tentang Merek dan atau Pasal 54 Ayat (1) Undang-undang Nomor 31 Tahun 2000 tentang Desain Industri dan atau Pasal 62 Ayat (1) Juncto Pasal 8 Ayat (1) huruf (a) Undang-undang Nomor 8 Tahun 1999 tentang perlindungan Konsumen. Maka Penyidik Ditreskrimsus Polda Sumatera Barat menyerahkan berkas perkara beserta barang bukti di serahkan kepada Jaksa Penuntut Umum Kejaksaan Negeri Padang Pariaman. Dengan diserahkannya berkas perkara oleh Penyidik ke Kejaksaan Negeri Padang Pariaman, maka penyidikan terhadap perkara Nomor: LP/B/133/III/2018/SPKT.SBR ini dinyatakan selesai.

Berangkat dari teori sistem peradilan pidana sebagaimana yang dikemukan oleh Herbet Packer beberapa model dalam sistem peradilan pidana, yaitu: ${ }^{11}$

1. Crime control model, yaitu pemberantasan kejahatan merupakan fungsi terpenting dan harus diwujudkan dari suatu proses peradilan pidana. Titik tekan dari model ini yaitu efktifitas, kecepatan dan kepastian. Pembuktian kesalahan tersangka sudah diperoleh di dalam proses pemeriksaan oleh petugas kepolisian.

\footnotetext{
${ }^{11}$ Romli Atmasasmita, Loc.Cit, hlm. 19.
} 
2. Due process model, yaitu menekankan pada fakta dari suatu kasus yang diperoleh melalui prosedur formal yang sudah ditetapkan oleh undang-undang. Prosedur itu penting dan tidak boleh diabaikan, melalui suatu tahapan pemeriksaan yang ketat mulai dari penyidikan, penangkapan, penahanan hingga peradilan.

Penegakan hukum yang dilaksanakan oleh penyidik Ditreskrimsus Polda Sumatera Barat terhadap perkara perkara tindak pidana hak atas merek pelumas kendaraan bermotor dalam Laporan Polisi Nomor: LP/B/133/III/2018/SPKT.SBR, telah sesuai dengan prinsip Due process model dalam sistem peradilan pidana yang menekankan pada fakta dari suatu kasus yang diperoleh melalui prosedur formal yang sudah ditetapkan oleh undang-undang.

Prosedur tersebut dilaksanakan oleh penyidik Ditreskrimsus Polda Sumatera Barat sesuai dengan ketentuan sebagaimana yang diatur dalam Undang-undang Nomor 8 Tahun 1981 tentang Kitab Undang-undang Hukum Acara Pidana berserta peraturan terkait, mulai dari penyelidikan selanjutnya penyidik melaksanakan penyidikan dengan diterbitkannya Surat Perintah Penyidikan Nomor: Sp.Sidik/19/III/2018/Ditreskrimsus, tanggal 21 Maret 2018 dan mengirimkan Surat Pemberitahuan Dimulainya Penyidikan Nomor: SPDP/09/III/2018/Ditreskrimsus, tanggal 26 Maret 2018 kepada Kejaksaan Negeri Padang Pariaman. Dalam hal melakukan penggeledahan Penyidik telah menerbitkan Surat Perintah Penggeledahan Nomor: SP.Dah/03/III/2018/Ditreskrimsus tanggal 21 Maret 2018 serta menerbitkan Surat Perintah Penyitaan Nomor: SP.Sita/04/III/2018/Ditreskrimsus tanggal 21 Maret 2018 dan melaporkan kepada Ketua Pengadilan Negeri Padang Pariaman untuk mendapatkan persetujuan penyitaan.

Sehingga dari seluruh rangkaian pemeriksaan yang telah dilakukan oleh Penyidik Ditreskrimsus Polda Sumatera Barat terhdap perkara tindak pidana hak atas merek pelumas kendaraan bermotor sebagaimana dalam Laporan Polisi Nomor: LP/B/133/III/2018/SPKT. SBR telah memenuhi unsur-unsur penegakan hukum yaitu adanya kepastian hukum, kemanfaatan dan keadilan.

Selain itu, jika mengacu pada teori perlindungan hukum sebagaimana yang dikemukakan oleh Philipus M. Hadjon pada bab sebelumnya, maka penegakan hukum oleh Ditreskrimsus Polda Sumatera Barat terhadap perkara tindak pidana hak atas merek pelumas kendaran bermotor dalam perkara Laporan Polisi Nomor: LP/B/133/III/2018/SPKT.SBR telah memberikan perlindungan hukum baik bagi pemegang hak atas merek yakni PT. Federal Karyatama maupun terhadap masyarakat sebagai konsumen. Karena dari hasil penelusuran peneliti, terhadap perkara ini telah diputus oleh Majelis Hakim Pengadilan Negeri Padang Pariaman dalam Putusan Nomor: 226/Pid.Sus/2018/PN.Pmn yang menjatuhkan hukuman terhadap terdakwa Masri Pgl Mas dengan hukuman pidana penjara selama 8 (delapan) bulan dengan masa percobaan 1 (satu) tahun.

Dari hasil pembahasan diatas, peneliti menyimpulkan bahwa penegakan hukum terhadap perkara tindak pidana hak atas merek pelumas kendaraan bermotor sebagaimana melanggar ketentuan Pasal 100 dan atau Pasal 102 Undang-undang Nomor 20 Tahun 2016 tentang Merek dan atau Pasal 54 Ayat (1) Undang-undang Nomor 31 Tahun 2000 tentang Desain Industri dan atau Pasal 62 Ayat (1) Juncto Pasal 8 Ayat (1) huruf (a) Undang-undang Nomor 8 Tahun 1999 tentang Perlindungan Konsumen, dalam laporan 
polisi nomor: LP/B/133/III/2018/SPKT.SBR oleh Ditreskrimsus Polda Sumatera Barat telah sesuai dengan ketentuan peraturan perundang-undangan.

\section{B. Kendala Yang Dihadapi Penyidik Direktorat Reserse Kriminal Khusus Polda Sumatera Barat Dalam Penegakan Hukum Tindak Pidana Hak Atas Merek Pelumas Kendaraan Bermotor Pada Laporan Polisi Nomor: LP/B/133/III/2018/SPKT.SBR}

Penegakkan hukum pidana di Indonesia menempatkan Kepolisian yang memiliki tugas sebagai penyelidik dan penyidik sebagai garda utama dalam sistem peradilan pidana. Karena apabila terjadi suatu tindak pidana maka pihak kepolisian lah yang pertama kali menangani dan memproses guna menegakkan hukum yang berlaku. Apabila suatu peristiwa sudah ditangani oleh pihak kepolisian dari proses penyelidikan sampai dengan penyidikan maka selanjutnya perkara tersebut akan dilimpahkan ke kejaksaan.

Sebelum membahas mengenai kendala dalam penegakan hukum oleh penyidik Direktorat Reserse Kriminal Khusus (Ditreskrimsus) Polda Sumatera Barat, maka penulis akan menyajikan terlebih dahulu faktor-faktor yang mempengaruhi penegakan hukum menurut Soerjono Soekanto sebagai berikut: ${ }^{12}$

1. Faktor Hukum, yakni praktik penyelenggaraan hukum di lapangan ada kalanya terjadi pertentangan antara kepastian hukum dan keadilan, hal ini disebabkan oleh konsepsi keadilan merupakan suatu rumusan yang bersifat abstrak, sedangkan kepastian hukum merupakan suatu prosedur yang telah ditentukan secara normatif. Justru itu, suatu kebijakan atau tindakan yang tidak sepenuhnya berdasar hukum merupakan sesuatu yang dapat dibenarkan sepanjang kebijakan atau tindakan itu tidak bertentangan dengan hukum. Maka pada hakikatnya penyelenggaraan hukum bukan hanya mencakup law enforcement, namun juga peace maintenance, karena penyelenggaraan hukum sesungguhnya merupakan proses penyerasian antara nilai kaedah dan pola perilaku nyata yang bertujuan untuk mencapai kedamaian.

2. Faktor Penegakan Hukum, yakni fungsi hukum, mentalitas atau kepribadian petugas penegak hukum memainkan peranan penting, kalau peraturan sudah baik, tetapi kualitas petugas kurang baik, ada masalah. Oleh karena itu, salah satu kunci keberhasilan dalam penegakan hukum adalah mentalitas atau kepribadian penegak hukum.

3. Faktor Sarana atau Fasilitas Pendukung yaitu mencakup perangkat lunak dan perangkat keras, salah satu contoh perangkat lunak adalah pendidikan. Pendidikan yang diterima oleh Polisi dewasa ini cenderung pada hal-hal yang praktis konvensional, sehingga dalam banyak hal polisi mengalami hambatan di dalam tujuannya, diantaranya adalah pengetahuan tentang kejahatan komputer, dalamtindak pidana khusus yang selama ini masih diberikan wewenang kepada jaksa, hal tersebut karena secara teknis yuridis polisi dianggap belum mampu dan belum siap. Walaupun disadari pula bahwa tugas yang harus diemban oleh polisi begitu luas dan banyak.

4. Faktor Masyarakat yaitu penegak hukum berasal dari masyarakat dan bertujuan untuk mencapai kedamaian di dalam masyarakat. Setiap warga masyarakat atau kelompok sedikit banyaknya mempunyai kesadaran hukum, persoalan yang timbul adalah taraf

\footnotetext{
${ }^{12}$ Soerjono Soekanto, Faktor-Faktor, Loc.Cit, hlm. 42.
} 
kepatuhan hukum, yaitu kepatuhan hukum yang tinggi, sedang, atau kurang. Adanya derajat 23 kepatuhan hukum masyarakat terhadap hukum, merupakan salah satu indikator berfungsinya hukum yang bersangkutan.

5. Faktor Kebudayaan yaitu berdasarkan konsep kebudayaan sehari-hari, orang begitu sering membicarakan soal kebudayaan. Kebudayaan menurut Soerjono Soekanto, mempunyai fungsi yang sangat besar bagi manusia dan masyarakat, yaitu mengatur agar manusia dapat mengerti bagaimana seharusnya bertindak, berbuat, dan menentukan sikapnya kalau mereka berhubungan dengan orang lain. Dengan demikian, kebudayaan adalah suatu garis pokok tentang perikelakuan yang menetapkan peraturan mengenai apa yang harus dilakukan, dan apa yang dilarang.

Berangkat dari faktor-faktor yang mempengaruhi penegakan hukum menurut pendapat Soerjono Soekanto diatas, maka kendala dalam penegakan hukum oleh Ditreskrimsus Polda Sumatera Barat terhadap tindak pidana hak atas merek pelumas kendaraan bermotor pada Laporan Polisi Nomor: LP/B/133/III/2018/ SPKT.SBR, terdapat kendala-kendala sebagai berikut:

\section{Terkait Faktor Hukum}

Dari faktor hukum, menemukan kendala dimana perkara tindak pidana hak atas merek atau terhadap perkara yang berkaitan dengan Hak Kekayaan Intelektual merupakan tindak pidana delik aduan sesuai dengan Pasal 103 Undang-undang Nomor 20 Tahun 2016 tentang Merek dan Indikasi Geografis yang menyebutkan bahwa tindak pidana sebagaimana dimaksud dalam Pasal 100 sampai dengan Pasal 102 merupakan delik aduan sehingga dalam melaksanakan penegakan hukum baru dapat dilakukan jika ada pengaduan dari pemegang hak atas merek yang dirugikan. Dengan kata lain apabila Kepolisian mengetahui adanya dugaan tindak pidana hak atas merek ini, sepanjang tidak ada yang membuat pengaduan maka Kepolisian tidak dapat melaksanakan penegakan hukum terhadap dugaan tindak pidana tersebut.

Selain itu, hal ini berkaitan juga dengan kepentingan konsumen yang dirugikan akibat perbuatan pelaku tindak pidana hak atas merek pelumas kendaraan bermotor, dimana konsumen membeli barang atau produk yang tidak sesuai dengan barang atau produk resmi PT. Federal Karyatama, sehingga menimbulkan kerugian bagi konsumen. Akan tetapi sebagai konsumen tidak dapat melaporkan tindak pidana hak atas merek tersebut karena tindak pidana ini merupakan delik aduan yang hanya dapat dilakukan oleh pihak yang berwenang atas merek tersebut, hanya saja sebagai konsumen dapat melaporkan dari segi perlindungan konsumen saja.

\section{Terkait Faktor Penegak Hukum}

Dalam pelaksanaan penyidikan juga tidak dapat terhindar dari kendala-kendala yang menghambat berjalannya proses pengakan hukum seperti halnya faktor penegak hukum yakni kurangnya personil yang memiliki keahlian khusus, dalam hal ini berkaiatan dengan penanganan perkara tindak pidana hak atas merek. Hal ini dikarenakan kebutuhan institusi yang mendesak sehingga seorang personil yang belum mengikuti pendidikan kejuruan untuk mendapat keahlian untuk masuk ke dalam satuan kerja baru dimasukkan ke dalam satuan kerja tersebut. Idealnya seorang personil Polri sebelum masuk ke dalam suatu satuan kerja harus mengikuti Dikjur (pendidikan kejuruan) terlebih dahulu untuk keoptimalan dalam menjalankan 
tugasnya kelak namun dengan kebutuhan institusi dan masih terbatasnya pelaksanaan Dikjur maka sering kali personil yang belum mengikuti Dijkur harus masuk ke dalam satker yang baru bagi personil tersebut. ${ }^{13}$

Selain itu jika mengacu pada Peraturan Kepala Kepolisian Nomor 22 Tahun 2010 tentang Susunan Organisasi dan Tata Kerja Pada Tingkat Kepolisian Daerah, tanggal 28 September 2010, jumlah peronil Penyidik dan Penyidik Pembantu yang seharusnya ada pada Sub Direktorat I perindustrian, perdagangan dan asuransi (Indagsi) adalah 31 (tiga puluh satu) personil yang dibagi dalam 4 (empat) Unit.

Namun kenyataannya saat ini jumlah personil Sub Direktorat I perindustrian, perdagangan dan asuransi (Indagsi) Ditreskrimsus Polda Sumatera Barat hanya terdiri dari 13 (tiga belas) personil atau kurang 28 (dua puluh delapan) personil. Minimnya jumlah personil penyidik dan penyidik pembantu pada Subdit I Indagsi tersebut tentu saja berpengaruh pada pelaksanaan tugas, apalagi dibandingkan dengan fenomena perkembangan tindak pidana khusus yang semakin kompleks di bidang perindustrian, perdagangan dan asuransi, ditambah lagi dengan tidak semua penyidik pembantu bisa memahami mekanisme proses penyidikan tidak pidana khusus di bidang bidang perindustrian, perdagangan dan asuransi.

\section{Terkait Faktor Masyarakat}

Kendala terkait faktor ini yaitu kurangnya partisipasi masyarakat, sehingga penegakkan hukum tidak akan dapat berjalan dengan baik tanpa adanya partisipasi dari masyarakat. Dalam hal tindak pidana terhadap hak kekayaan intelektual juga dibutuhkan partisipasi dari masyarakat, karena delik ini merupakan delik aduan maka apabila terjadi pemalsuan terhadap merek yang indikasinya bisa dilihat dengan harga yang dijual dengan harga yang dibawah standar ataupun kualitas dari produk tidak sesuai dengan standar produk yang asli maka masyarakat dapat melakukan pelaporan kepada pihak yang berwajib agar praktek haram ini dapat diusut, namun yang sering terjadi adalah apabila masyarakat menemukan hal tersebut maka masyarakat umumnya hanya akan menghindari untuk membeli produk palsu tersebut dan memilih membeli di tempat yang lain tanpa memikir kalau sebenarnya hal tersebut sudah merupakan pelanggaran hukum. Akan tetapi jika mengacu pada faktor hukum diatas, hal ini berkaitan dengan sifat dari tindak pidana hak atas merek yang merupakan delik aduan, sehingga masyarakat hanya dapat melaporkan yang berkaitan dengan perlindungan konsumen saja.

Namun demikian, menurut hemat peneliti secara khusus dalam penegakan hukum terhadap tindak pidana hak atas merek sebagaimana dalam Laporan Polisi Nomor: LP/B/133/III/2018/SPKT.SBR, Penyidik Direktorat Reserse Kriminal Khusus Polda Sumatera Barat tidak mengalami kendala yang berarti, dimana sejak awal perkara ini dimulai sampai dengan pemeriksaan penyidikan tersangka bersikap koperatif dan menyadari kesalahannya, demikian juga dengan para saksi dan ahli yang memberikan keterangan sesuai dengan fakta-fakta yang ditemukan oleh penyidik, sehingga penyidikan dapat berjalan sesuai dengan ketentuan baik dalam Undang-

\footnotetext{
${ }^{13}$ Hasil Wawancara dengan AKBP Yunizar Yudhistira, selaku Penyidik Ditreskrimsus Polda Sumatera Barat pada tanggal 3 Mei 2021 di ruang Ditreskrimsus Polda Sumatera Barat.
} 
undang Nomor 8 Tahun 1981 tentang Kitab Undang-undang Hukum Acara Pidana, serta Peraturan Kepolisian Negara Republik Indonesia Nomor 6 Tahun 2019 tentang Pencabutan Peraturan Kepala Kepolisian Negara Republik Indonesia Nomor 14 Tahun 2012 Tentang Manajemen Penyidikan Tindak Pidana.

\section{KESIMPULAN}

Berdasarkan hasil penelitian, pembahasan dan analisis yang telah diuraikan pada babbab sebelumnya dapat disimpulkan hal-hal sebagai berikut:

1. Penegakan hukum terhadap tindak pidana hak atas merek pelumas kendaraan bermotor oleh Penyidik Direktorat Reserse Kriminal Khusus Polda Sumatera Barat pada Laporan Polisi Nomor: LP/B/133/III/2018/ SPKT.SBR diawali adanya laporan dari kuasa hukum PT. Federal Karyatama terhadap Masri Pgl Mas selaku pemilik Toko Aneka Sepeda. Kemudian penyidik menindak lanjuti laporan tersebut dengan melakukan penyelidikan berupa pengecekan bersama dengan pelapor beserta tim dari PT. Federal Karyatama menuju Toko Aneka Sepeda dan dari hasil pengecekan ditemukan adanya dugaan tindak pidana hak atas merek yang dilakukan oleh pemilik Toko Aneka Sepeda sehingga penyidik melakukan upaya paksa berupa mengamankan pelaku dan melakukan penyitaan terhadap barang bukti yang ditemukan. Berdasarkan pada fakta-fakta yang terungkap di penyidikan, baik keterangan para saksi, keterangan ahli, barang bukti, serta keterangan tersangka menetapkan Masri Pgl Mas sebagai tersangka dengan menerapkan Pasal 100 dan atau Pasal 102 Undang-undang Nomor 20 Tahun 2016 tentang Merek dan atau Pasal 54 Ayat (1) Undang-undang Nomor 31 Tahun 2000 tentang Desain Industri dan atau Pasal 62 Ayat (1) Jo Pasal 8 Ayat (1) huruf a Undang-undang Nomor 8 Tahun 1999 tentang perlindungan Konsumen dan terhadap perkara tersebut telah dinyatakan lengkap (P.21) oleh Jaksa Penuntut Umum dengan dilaksanakannya kegiatan penyerahan tersangka dan barang bukti dari penyidik kepada Jaksa Penuntut Umum di Kejaksaan Negeri Padang Pariaman dan berdasarkan Putusan Nomor:226/Pid.Sus/2018/PN.Pmn Majelis Hakim telah menjatuhkan hukuman pidana penjara terhadap terdakwa Masri Pgl Mas selama 8 bulan dengan masa percobaan selama 1 tahun.

2. Kendala yang dihadapi Penyidik Direktorat Reserse Kriminal Khusus Polda Sumatera Barat dalam penegakan hukum tindak pidana hak atas merek pelumas kendaraan bermotor pada Laporan Polisi Nomor: LP/B/133/III/2018/SPKT.SBR meliputi, pertama kendala faktor hukum dimana tindak pidana hak atas merek bersifat delik aduan, sehingga kepolisian hanya dapat bertindak setelah adanya laporan dari pemegang hak atas merek yang dirugikan walaupun implikasi perbuatan tersebut tidak hanya merugikan pemegang hak atas merek tetapi juga masyarakat luas sebagai konsumen. Kedua kendala faktor penegak hukum yaitu masih terbatasnya pelaksanaan pendidikan kejuruan bagi personil Subdit I Indagsi Direktorat Reserse Kriminal Khusus Polda Sumatera Barat, sehingga berpengaruh pada keoptimalan dalam pelaksanaan tugas penyidikan tindak pidana hak atas merek. Ketiga faktor masyarakat yaitu kurangnya partisipasi masyarakat dalam memberikan informasi terkait adanya dugaan tindak pidana hak atas merek. 


\section{DAFTAR PUSTAKA}

Abdulkadir Muhammad, Kajian Hukum Hak Kekayaan Intelektual, Citra Aditya Bakti, Bandung, 2015.

Berita acara pemeriksaan dari sample uji laboratorium dalam resume laporan polisi nomor LP/B/133/III/2018/SPKT.SBR

Harkristuti Harkrisnowo, Rekonstruksi Konsep Pemidanaan: Suatu Gugatan Terhadap Proses Legislasi dan Pemidanaan di Indonesia, Orasi pada Upacara Pengukuhan Guru Besar Tetap dalam Ilmu Hukum di FH UI Depok, 8 Maret 2003.

Munir Fuadi, Pengantar Hukum Bisnis, PT. Citra Aditya Bakti, Bandung, 2012.

Pra penelitian dalam resume laporan polisi nomor LP/B/133/III/2018/SPKT.SBR.

Rachmadi Usman, Hukum Hak dan Kekayaan Intelektual, Perlindungan dan Dimensi Hukumnya di Indonesia. PT. Alumni, Bandung, 2003.

Sophar Maru Hutagalung, Hak Cipta Kedudukan \& Peranannya dalam Pembangunan, Sinar Grafika, Jakarta, 2012.

https://www.kompas.com, Polda Sumbar Sita Ribuan Oli Palsu, Pemilik Toko Jadi Tersangka diakses pada 6 Februari 2021, Pkl. 04.00 Wib 